\title{
Lorca's Anorexics. Hunger Strike in the Cause of Selfhood
}

\author{
LISA CLUGHEN
}

\section{The Nottingham Trent University}

Lorquian criticism is anorexic. Or rather, it bears an anorexic, unmistakably modern, relationship with the self: it thinks in binaries and fixities, yet it is aware that the self is anything but binary or fixed. I am of course referring in the first instance to the humanist tendencies of Lorquian criticism ${ }^{1}$ and in the second to post 1980 poststructuralist readings. ${ }^{2}$ The humanist approach to Lorca has thought in whole categories of selfhood in an attempt to fix the self as knowable. It knows that the subject is an amalgam of such binary forces as the rational and the emotional and it knows that the female self bears a distinct relation to the emotional side of the binary. Thus Lorca's humanist critics have been able to limit women as maternal, (hetero)sexual, given to the passions, unpredictable and so on. ${ }^{3}$ The poststructuralist approach to Lorca shatters all talk of dualism, brings to the fore ontologies of a displaced self, and renders both chimeric and power-laden humanist reifications of the total self. Inspired by feminist critiques that it is useful to consider subjectivity as both limited and boundless, ${ }^{4}$ in this paper I shall argue that we must recognize and re-negotiate both humanist and poststructuralist perspectives when discussing the subject in Lorca's works. For the self may well be fragmented, but Lorca's female characters describe their bodies in ways which suggest that they do not always experience them as such, conceiving of them instead as complete entities which form the integral and troublesome half of a dualistically split self. These experiences involve them in destructive practices and feelings which have been glossed over by poststructuralist appeals to freer conceptions of the self. Here, I will endeavour to listen to Lorca's female characters when they talk of limits, when conceptions of their selves as fluid are not central to their being. I therefore propose that it is necessary to read for 
dualism and sameness, for the ringfenced nature of the mind/body dualism has been fundamental to the creation of limits and has produced the bodily experience of pain, distaste, disgust, and downright hatred for the body which provides a ground for Lorca's characters' being in the (theatrical) world.

Writers on anorexia have consistently pointed to the limited and yet boundless characteristics of the illness - people with anorexia respond to overwhelming feelings of defferal by imposing limits on their existence. ${ }^{5}$ Taking up the notion of both limits and deferral as founding moments of the self conception of the anorexic, cultural feminist interest in anorexia is in how the bodies of people suffering from anorexia have inscribed upon them but are also used as a rather devastating response to culturally dominant proscriptions about the self. Working with Susie Orbach's ${ }^{6}$ description of anorexia as 'a hunger strike in the cause of selfhood', in this paper I shall, using García Lorca's texts to situate my explorations, discuss the issue of selfhood and anorexia: what is the self conception of the anorexic and how does representation relate to practice? To these ends, I shall deploy the work of Susan Bordo ${ }^{7}$ who takes up and applies to anorexia the point, widely discussed by feminists, that the dominant version of the self in the West is dualistic. What is important to feminist analysis is that dualistic constructions of the self frequently valorise the body (and woman in what is posited as her intimate relationship with the body $)^{8}$ as negative and can be used to legitimate practices which act upon this negative valuing of the body/woman. Anorexia is one such practice. The ways in which we represent our bodies to our selves, in other words, have implications for the ways in which we live in them - discourse, as Judith Butler ${ }^{9}$ says, has the power to materialise its effects.

Nevertheless, although Western constructions of the self as dualistic and the practices which issue from them might at some level be sedimented in and compelled by discourse, they are, as poststructuralist theory has urged, never fixed by it and so the self 
is inscribed yet has agency at the same time. ${ }^{10}$ Anorexics might, therefore, construct an ideal, rigid notion of the self but only on an awareness that they have to struggle, and indeed never quite manage, to achieve it. ${ }^{11}$ Such readings of anorexia motivate my own readings of selfhood in Lorca's texts. I read Lorca's characters as constructing their selves through dualist categories of mind/body, man/woman, but also argue that their constructions never hold. In this article, however, I emphasise the structuring process of the self rather than its concomitant destructuring. I am interested here in the ways in which anorexics and Lorca's characters try to fix a self in the mind and refuse Otherness via a discursive opposition to a not-self which is posited as the body. The discursive attempt at the fixing of gender boundaries will, therefore, shape the main part of this paper and will be used to infuse feminist ideas that representations are intimately linked with lived realities. ${ }^{12}$

Reading representations and determining effects is, of course, a complex, unending affair. I am not saying that all people who live within a dualistic paradigm will develop eating disorders (there is of course more to eating disorders than discourse alone), only that people who have eating disorders tend to situate themselves within dualist paradigms. ${ }^{13}$ Striving to avoid a simplistic equation between discourse and its effects, I shall conclude by arguing briefly that the discursive selves posited by Lorca's characters are always subject to failure so people are in no simple way positioned by discourse. I shall locate this within a therapeutic framework which works along the lines that people can, by breaking away from destructive dualist thinking, also break away from destructive eating disorders.

I shall begin with discourse as a site where the idea of a 'real' self is constructed as oppositional to a not-self. Bordo ${ }^{14}$ identifies four key features of Western philosophical discourse through which this is attempted. These features are: first, the 
body is conceptualised as alien, second, as confinement, third, as enemy and fourth as that which threatens and exceeds attempts at control.

The first image establishes a dualistic split between mind and body by representing the body as 'alien, as the not-self, the not-me' and rendering the mind the real 'me'. ${ }^{15}$ This is an important part of the self representation of the anorexic - writers on eating disorders stress that sufferers often feel a profound sense of alienation from their bodies. ${ }^{16}$ Such representation impacts upon the lived experience of the body - bodily sensations are experienced as things which are Other to the self, things which happen to the self. So, typical of anorexic discourse is that she "neither owns the body nor its sensations'. ${ }^{17}$ Thus one of Hilde Bruch's ${ }^{18}$ patients can say she ate breakfast because her stomach wanted it, not her 'self'.

Once the mind/body dualism has been established and the body is fully situated as alien, the Other of reason, it is possible to ascribe to the body qualities which are not present in the mind. One such quality is that the body impedes the self. In this the idea of control is pivotal: the body is an Other which functions to control the anorexic. This is often conceived in imagery which suggests confinement or limitation. ${ }^{19}$ Prominent in this is the image of the soul/mind/will being dragged (especially downwards towards the earth or death) by the body. So the body inhibits human freedom by consuming us, holding us back and especially keeping us away from reason. It thus takes on a negative value and is frequently perceived in Western philosophy as 'a 'prison', a 'swamp', a 'cage', a 'fog', ${ }^{20}$ indeed as anything that holds the soul/mind or will in the shackles from which they struggle to escape.

The third image Bordo ${ }^{21}$ discusses is that of the enemy body. The body is enemy, amongst other things, because it has hungers. It is the hungering body which takes the Western philosopher and the anorexic away from their real selves - the mind - and is responsible for feelings of defferal.from it. The fear of hunger is a central part of the 
experience of people with anorexia who, according to Bordo, ${ }^{22}$ are often as obsessed with hunger as with being slim. One woman in Bordo's ${ }^{23}$ study verbalises this fear '[H]unger, or the dread of hunger, pursues me all morning ... Even when I am full, I am afraid of the coming hour in which hunger will start again'.

This prepares us for Bordo's final idea. ${ }^{24}$ Central to Western philosophical discourse on the body is the idea that these hungers are so disturbing they can easily become out of control, take over and even kill the self. This rings true for anorexics, who fear that their bodies can become too hungry, too desiring. Indeed it is pivotal to the anorexic discourse on the hungry self summed up by the women in Bruch's ${ }^{25}$ study who express a fear of taking one more bite lest they spiral out of control. So the body/women want more than a bite to eat, they want to consume everything. The body/woman is excessive, far too much. As another woman puts it, here pointing to the link between discourse on the body and femininity:

You know, the anorexic is always convinced she is taking up too much space, eating too much, wanting food too much. I've never felt that way, but I've often felt that I was too much - too much emotion, too much need, too loud and demanding, too much there, if you know what I mean. ${ }^{26}$

\section{THE ALIEN BODY}

Turning to Lorca's texts, I shall discuss two techniques which produce the idea of the body as the alien Other. First, the characters describe the body and its emanations the passions as having a material reality of their own (in the form of a body). Second, the characters can position themselves as objects of this alien being for the body also has an immaterial reality (in the form of a will). 
Let us begin with Blood wedding ${ }^{27}$ - perhaps the most extreme exponent of the alienated, independent body. I shall concentrate on the flight scene (59-63), in which the newly married Bride flees from the wedding celebrations with her sweetheart Leonardo, as it is a time when passions are high and the spotlight therefore turned onto the body. The Bride describes her pain and emotion through the image of fire and glass which attack her from without 'qué fuego / me sube por la cabeza!/ ¡Qué vidrios se me clavan en la lengua!' (60). Thus the passions are embodied: they have a separate, material reality of their own. Leonardo echoes this by describing how he tried to prevent such overpowering passions from taking over by building a wall between himself and the Bride (61), but was taken to her anyway by the horse, the carrier or, rather, the embodiment of his desires (61). So alienated is the body, in fact, that the Bride talks as if she does not own it: her hands are appended to her body, but have an independent status of their own 'estas manos que son tuyas' (60).

For further examples of the alien body, we might consider the Mother's worry, fury and anguish which also have a physical form - her worry is 'una pedrada en la frente' (6) and the cry which resides within her, she tells us is 'siempre puesto de pie' (41). The Bride has 'un mal aire en el centro' (28) and her worry and pain are represented in the form of air 'aires de sosiego' (36) or a blow to the head 'un golpe en las seines' (48). The body, thus represented, is most definitely the 'not me'.

A sense of alienation from the body and its effects is also prevalent in Yerma, ${ }^{28}$ though my discussion will concentrate on the 'prado de pena' lament (116). Here, Yerma addresses her body as a discrete object, something which she owns 'estos dos manantiales que yo tengo' (116), something which just happens to be there like those 'pechos ciegos bajo mi vestido' (116). Her breasts are distinct physical or metaphysical entities: they are 'dos manantiales' (116) and 'dos pulsos de caballo' (116) respectively. They have their own physical or non-physical attributes: they are 'ciegos' (116) or 'palomas sin ojos' (116). And her body has its own, separate experiences or needs: as the 
anorexic spoke of her stomach, rather than herself as being hungry, here it is Yerma's womb which has an independent life 'nuestro vientre guarda tiernos hijos' (116). All this bestows upon the body and the passions a separateness from Yerma's 'real self' (now most definitely the non-body) and grants them an agency of their own, an agency as individual as that of a human. When the body is conceived in this way, when she feels that she 'has' this body (and theoretically has agency over it) but that it also has her (she is its object), it is wholly appropriate for Yerma to talk about and then to actually address her body as if it were a separate entity. Indeed the speech is both a lament to her body ‘Ay pechos ciegos bajo mi vestido! / ¡Ay palomas sin ojos ni blancura!’ (116) as well as about it '¡Ay qué prado de pena!’ (116). The body, thus represented as a separate physical reality, is most definitely the 'not me', the locus and expression of the Other.

The characters in La casa de Bernarda Alba, ${ }^{29}$ consistently objectify the body with reference to it as something they possess - Adela, for example, says 'tengo mal cuerpo' (71), 'por encima de mi madre saltaría para apagarme este fuego que tengo levantado por piernas y boca' (73), and Martirio 'tengo el corazón lleno de una fuerza tan mala, (...)' (103). And once more reification takes place via the transference of the body's effects into separate physical entities. Like Leonardo, Adela is linked with the horse, the 'mulilla sin desbravar' (78), which leads to an easy association between the horse and its wild passions with Adela and hers. And María Josefa's lamb gives a physical reality to the pain of her stifled maternal power, the futility of her sexuality. The body, then, is separate, an object which can easily be divorced from Lorca's characters' real self, as Magdalena puts it 'ni nuestros ojos siquiera nos pertenecen' (76).

The second technique in this production of the alien body positions the characters as the objects of the body which, having a will of its own, acts upon them. So the passions happen to the characters. Fury happens to the Bride 'se me calienta el alma de que vengas a verme’ (31), as does worry ‘'Aires de sosiego le manan los ojos!' (36). 
Desperation happens to the Mother 'pasan los meses y la desesperación me pica en los ojos y hasta en las puntas del pelo' (4), as does pain 'me duele hasta la punta de las venas' (41). In the flight scene the Bride positions herself as the object of the fire, glass and beauty. Here, as elsewhere in Lorca, there is a proliferation of object pronouns to emphasise this 'iqué fuego / me sube por la cabeza! / ¡Qué vidrios se me clavan en la lengua!' (60). And the horse, representing Leonardo's desires, can usurp him of its own volition 'pero montaba a caballo / y el caballo iba a tu puerta' (61). The passions, then, happen to the characters, they are not part of them.

Yerma is also the object of this independent reality which is the body which does things to her and of its own accord. Her breasts, she tells us 'hacen latir la rama de mi angustia' (116), her blood, she says 'me está clavando avispas en la nuca' (116) and the air, the traditional representative of the passions 'me ofrece dalias de dormida luna!' (116). She knows full well that her body can do things to her over which she has no control, when Víctor took her in his arms she tells of how 'me entró un temblor que me sonaron los dientes' (80). And sometimes she fears it for this precise reason 'cada mujer tiene sangre para cuatro o cinco hijos, y cuando no los tienen se les vuelve veneno, como me va a pasar a mí' (70). So quite in spite of herself, her body can fill her with negative emotion 'me estoy llenando de odio' (81) - she exists at its behest.

Such notions of the willful alien body carry through to La casa de Bernarda Alba. Martirio explains how the evil force in her heart is killing her, being 'una fuerza tan mala que sin quererlo yo, a mí misma me ahoga' (103). Angustias tells us that 'la envidia la come’ (71), 'se le está poniendo mirar de loca’ (71), ‘casi se me salía el corazón por la boca' (69). And Poncia, describing her meeting with her husband Evaristo, says 'me corría el sudor por todo el cuerpo' (70). So again the passions happen to the characters, the body objectifies the person to whom it is attached and dictates to them, holds power 
over them. This is part and parcel of the body's processes, as Adela says 'nadie podrá evitar que suceda lo que tiene que suceder' (73).

\section{THE CONFINING BODY}

The above discourse has firmly established the idea that the alien body confines the characters. This might, as Bordo ${ }^{30}$ says, be conceived through prison imagery. In the flight scene, the Bride uses the image of shackles quite explicitly saying that she wants what is holding them together, their passion, removed 'quita de mi cuello honrado/ el metal de esta cadena' (60). Yerma speaks of her blood as imprisoning her quite explicitly or limiting her by inflicting pain upon her ‘iAy qué dolor de sangre prisionera / me está clavando avispas en la nuca!' (116). Furthermore, and comparing to Bordo's ${ }^{31}$ assertion that the body confines its object by dragging her/him along, the Bride tells Leonardo 'no puedo oír tu voz. (...) Y me arrastra, y sé que me ahogo, pero voy detrás' (32). And Adela defends her 'self' with reference to the dragging body 'Martirio: ¡He visto cómo te abrazaba! Adela: Yo no quería. He sido como arrastrada por una maroma’ (86).

What the body is dragging these characters away from is reason. This is explicit in the flight scene where the Bride (60) laments that the fire and sheaths of glass are attacking both her mind (cabeza) and speech (lengua) and is completed by her cry ' $\mathrm{A}$ Ay qué sinrazón! No quiero / contigo cama ni cena, / y no hay minuto del día / que estar contigo no quiera, / porque me arrastras y voy, / y me dices que me vuelva / y te sigo por el aire / como una brizna de hierba' (61). The body, then, is not only alien Other, it is alien Other because it is oppositional to reason.

\section{THE ENEMY BODY}


Having introduced the body as an enemy invader, as the place where Otherness takes the place of reason, I would like to take the idea of invasion or attack as central to conceptualisation and production of what Bordo ${ }^{32}$ calls 'the enemy body'. The body is the foe because it violently threatens and sometimes injures the 'real self'. In other words, from its location in the negative side of binary thought, the body threatens reason.

That the body acts upon Lorca's characters in the manner of an attack is evident in the violence they identify in its processes and the pain or injuries they sustain a result of it. Returning to the example ‘ $i A y$, qué lamento, qué fuego / me sube por la cabeza! / ¡Qué vidrios se me clavan en la lengua!' (60) we have the Bride identifying her body as attacking her reason (cabeza, lengua) with weapons of battle or violence (fuego, vidrios). Similarly, anger happens to and overcomes the Bridegroom in a rather excessive, violent and threatening way which threatens to destroy his self by preventing him from breathing 'y vamos pronto, que siento los dientes de todos los míos clavados aquí de una manera que se me hace imposible respirar tranquilo' (57). Adela takes up the imagery of fire, locates it as a weapon inherent in the body which hounds her 'todo el pueblo contra mí, quemándome con sus dedos de lumbre' (102). But it is Martirio who gives the most potent expression to this idea when, appealing to reason to mount a counterattack on the body, she says 'déjame decirlo con la cabeza fuera de los embozos. ¡Sí! Déjame que el pecho se me rompa como una granada de amargura' (102).

Lorca's characters, then, are at war. They constantly refer to their existence as a war or battle. The Bride is experiencing 'una gran lucha interior' (46). The Mother's mind is in constant battle 'que tengo la cabeza llena de cosas de hombres y de luchas' (49). For her life itself is but a great battle 'mientras una vive, lucha' (49). Living in dualism, Lorca's characters live during war time - the females in Bernarda Alba, for instance, are living in a 'casa de guerra' (97). Sometimes the philosophical struggle they are in breaks out into full dramatic form, for example, in the hunt scenes of Bodas and 
Bernarda Alba - the Moon, beggar woman and the families of Bodas hunt the fleeing lovers, and in Bernarda Alba Paca la Roseta (56-7) and la Librada (86-87) are hunted down and Bernarda goes in pursuit of Pepe el Romano (104). We should indeed mark the words of the young boy in Bodas 'esto es una caza' (58). For, as the Bridegroom points out, it is no ordinary hunt, but a philosophical one 'la más grande que se puede hacer' (58). And there is no question now who, or rather what, the opponent is: they are at war with the body - each hunt scene is usually motivated by a character giving in to what is perceived as a bodily excess. It is in this context that we can situate Angustias' words to Adela towards the end of Bernarda Alba. As the house of Bernarda Alba is but a battleground where the main opponent is the body, it is imperative Adela does not leave with her 'cuerpo en triunfo' (104).

\section{THE UNCONTROLLABLE BODY}

The motif of the enemy body prepares us for the final image referred to by Bordo: ${ }^{33}$ the uncontrollable body. Hungers can become out of control, take over and even kill the self. For hungers, as people with anorexia will tell you, know no bounds. It is here, as I shall argue, that the overwhelming Other is gendered. And the gender of the body, the devouring Other, is female. I shall discuss one way in which this is produced. It comes through a series of motifs which dominated late $19^{\text {th34 }}$ and early $20^{\text {th } 35}$ century Western cultures: the all-consuming woman, the female vampire, castrator, or killer.

Visual images of blood sucking, devouring women run through the trilogy. After the deaths of the Bridegroom and Leonardo, the Bride returns 'teñida en sangre falda y cabellera' (68). After the death of her first son, the Mother says 'me mojé las manos de sangre y me las lamí con la lengua' (42). Yerma tells Juan 'es tu sangre (...) lo que deseo' 
(140). She also hints that, like an animal, she would not be opposed to licking clean her newborn child 'los animales los lamen, ¿verdad? A mí no me da asco de mi hijo' (133). And Adela looks voraciously and dangerously upon Pepe el Romano 'mirando sus ojos me parece que bebo su sangre lentamente' (74). Female vampires leap onto people, devour them and murder them. Thus Bernarda 'es capaz de sentarse encima de tu corazón y ver cómo te mueres durante un año sin que se le cierre esa sonrisa fría que lleva en su maldita cara' (46). And vampirish females tear at the flesh with their teeth stereotypically from the neck. Thus the Mother says 'tengo que no reconocerla, para no clavarla mis dientes en el cuello' (69).

To sum up, let us listen to the Bride. By appealing to the obstructions wrought quite naturally by the alien body, the Bride seeks to disavow her part in the flight, arguing with the Mother at the end that:

el otro me mandaba cientos de pájaros que me impedían el andar (...) Yo no quería, ;óyelo bien!; yo no quería. (...) pero el brazo del otro me arrastró como un golpe de mar, como la cabezada de un mulo, y me hubiera arrastrado siempre, siempre, siempre, aunque hubiera sido vieja y todos los hijos de tu hijo me hubiesen agarrado de los cabellos! (70)

These words bring together the four characteristics of the body we have been discussing. First we have the complete alienation and objectification of Leonardo's passionate body (el otro) via its representation as birds. The Other is seen as an attack on the bride's 'self' which was in active opposition to its will (yo no quería). Yet, in spite of her self, the body limits her will (me impedían el andar) and violently drags her away from her self (me arrastró como un golpe de mar). Her self, then, is the enemy of the 
body. And what is more, all of this is represented as natural and, therefore, uncontrollable (me hubiera arrastrado siempre).

If we take the aforementioned representations together then we can argue that all that is fearful is projected onto the body. The body asserts control on a self which the anorexic, Lorca's characters and Western philosophers describe as absolute - the mind. The body is dangerous, a potential murderer. And the body is woman. It is a discourse which, as Bordo ${ }^{36}$ says, runs through Western culture and, as I have discussed, reappears in the mouths of Lorca's women.

\section{REPRESENTATION, POWER AND CONTROL}

It is at this point, the point where the body is represented as potentially overwhelming, that the dangers of dualistic constructions of the self (however tenuous) become evident. They are especially dangerous to women. This, I believe, is one reason why we must stay with and interrogate the ways in which difference might be read as the offshoot of dualism, rather than hastily move to celebrate difference, as has perhaps been the case in Lorquian criticism. For a logical practice which issues out of dualistic discourse on the self is that the body, the site of difference to a real self, should be controlled before it controls and totally consumes or kills off the self. The mind/body dualism is, as Bordo ${ }^{37}$ says 'a practical metaphysics', which is easily translated, as the anorexic experience makes clear, into an incitement to battle with the body, a belief in the necessity of controlling the body by attacking it or even by killing it off. In other words, by drawing on the self/body division I have been describing in this paper, one can quite logically enter into war against the body. What is established in dualism is what Foucault ${ }^{38}$ calls the 'agonistic relation with the self'. The body is, in John Dwyer's ${ }^{39}$ words 'at war', 
dualistic discourse has prepared its subjects for battle and many have taken up the challenge. Indeed battling with the body guides the action in Lorca and the life experience of anorexics. And no matter how radical the challenge of the anorexic may be, it is a challenge which can destroy lives. This is central to my argument as it exemplifies not only the point that discourse can infuse experience, but that it can infuse it quite specific and dangerous ways which I shall now discuss.

One way of controlling the body, an anorexic way, is by refusing food. It is a strategy adopted by many of Lorca's characters. The Bride, refusing desire (which for her is a refusal of the body) tells Leonardo that she does not want food from him 'no quiero / contigo cama ni cena' (61). Yerma tells Juan 'come tú con tus hermanas. Yo no tengo hambre todavía' (116). And, according to Poncia, Bernarda neither eats nor wants anybody else to eat ' $i$ Quisiera que ahora, como no come ella, que todas nos muriéramos de hambre!' (45-46).

The issue of control also demands a specific reading of the move towards androgyny, bisexuality, or intersexuality in the texts. From the perspective of eating disorders, the move towards states which blur binary categories might be read as a strategy of control steeped in the negativity and fear heaped on the body by dualistic discourses. Indeed Bordo, ${ }^{40}$ citing Lui, describes how anorexic people often view the move towards androgyny as a way of gaining control over their insatiable, dangerous hungers (usually sexual) 'hunger and sexuality are psychically connected ... Sexuality ... is 'an abominable business' ... staying reed thin is seen as a way of avoiding sexuality, by becoming 'androgynous', Androgyny, from this position, is an act of power over the body/woman. And so androygyny, when used as a means of dealing with the out-ofcontrol body, becomes a locus of normalisation of the body/woman, rather than an unsettling of gender oppositions as Smith $^{41}$ has proposed. 
But the only way of fully controlling the body when living within the Western dualistic paradigm of the self is via a strategy which is so often deployed by characters in Lorca's dramas: to win the battle against the Other which the body represents, the body will have to be negated, it will have to die. This is a logic which becomes a brutal reality for many anorexics. According to the Eating Disorders Association of Great Britain ${ }^{42}$ 'anorexia nervosa has one of the highest rates of mortality for any psychiatric condition, estimated to run at around 13-20 per cent per annum'. And it is a logic which tempts many of Lorca's characters, indeed fuels his works - the Other invariably dies in Lorca. Thus the Bride beseeches Leonardo 'pon en mis manos de novia/ el cañón de la escopeta' (60), but it is Leonardo and the Novio, the Bride's 'Others' who die. It is a logic which speaks to Yerma - to deal with the problems presented by what she considers to be an impossible relationship between the self and the Other, she has to kill the Other. Bernarda battles constantly with death “¡Matadla! ¡Matadla!' (87), sees it as the only solution to the problematics of the self ‘¿La escopeta! ¿Dónde está la escopeta?’ (104) and seeks it out 'la muerte hay que mirarla cara a cara' (106). As with Yerma, Bernarda's dualistic understanding wins its battle to negate the body with the death of Adela, the character who most challenged it, her enemy Other. As Bernarda herself says 'una hija que desobedece deja de ser hija para convertirse en una enemiga' (90) so it is only 'logical' that Adela should die.

\section{BREAKING AWAY: BEYOND THE BINARY}

Those anorexics who do not take the battle to the extreme of death, however, bear a complex relationship with hunger. They express an awareness that hunger (the body/ the Other) cannot be negated - by denying that they are hungry, by expelling hunger, 
anorexics only compound their hunger. The female anorexic is very aware that the dualistic categories she uses to construct her existence are tenuous. ${ }^{43}$ For she remains, despite her controls, haunted by her hungers - as Orbach ${ }^{44}$ puts it 'she feels subject to that very monstrous desire she has tried to contain'. Her techniques are not working, the body cannot be controlled, the Other is part of the self and the anorexic might binge as the Other breaks through her rigid controls. Although the ever-present potential to break away from dualism is not the focus of this paper, I would like to stay with it for a moment for it does initiate a new and important direction to my argument.

In order to argue that discourse can produce certain effects, I have been applying a very specific meaning to representation in the texts which might seem to ignore the issue that meaning is contextual, fluid, terms always unstable and change possible. Discourse, as Butler ${ }^{45}$ says, is not a closed system. It does not necessarily follow that just because people represent themselves in certain ways they will act in a certain ways. Characters might deploy dominant discourses, but do not always attach dominant meanings to them, and even if they do, they do not necessarily act in accordance with the dominant meanings ascribed to them. If we return to the examples I cited with regard to women as vampires, for instance, what is interesting is that the characters might represent themselves as having the potential to be all-consuming vampires but rarely do they consume the blood of the Other (although some do, of course, and discourse does materialise its effects). These ruptures between representation and effect offer opportunities to challenge destructive ways of being - if our self concepts are ideas, albeit ideas which can become reality, we can start to ask where our ideas have come from, what consequences they may have for lived reality and whose interests they serve. We might also argue that people can refuse what is now only an idea rather than an absolute truth - we do not have to take up the imperatives we hear from discourse, we can be active even within rigid discourses. 
So the breakdown of dualisms allows the subject to break out of such confining, potentially murderous discourses. I will give one example from the end of Blood wedding to illustrate this point. Here, the Mother demonstrates an awareness that her rigid gender identity has been broken in so far as she is no longer a Mother - after all, all of her children have been killed. Connecting her relationship with food with her position as Mother, and thus her creation of a rigid identity, she calls herself 'una mujer que no tiene un hijo siquiera que poderse llevar a los labios' (69). What is interesting is that now she has been forced out of her identity, she says that her relationship with food (in its association with the knife) is not so problematic and this also removes the logic of death 'dormiré sin que ya me aterren la escopeta o el cuchillo' (69). Here we have the therapeutic idea that breaking away from rigid, dualistic patterns of thinking also means that she will have to attack the body no longer - the gun is no longer pointed at her. Accepting that the self is Other, then, offers a sense of reconciliation with the body. For, if the self is conceived as flowing and non-oppositional, there is no oppositional 'Other' to attack. The idea that people can overcome their eating disorders is, as Orbach ${ }^{46}$ says, $^{2}$ essential to therapy. Although, of course, it is not realistic in a therapeutic situation to expect change to occur as rapidly as the Mother here suggests and setbacks are a realistic part of therapy, artistic license allows Lorca to stage what is a crucial part of the recovery from eating disorders such as anorexia: the idea that they are surmountable, there are moments of progress and there are people who have overcome them.

My last point is crucial to my overall approach to Lorca's texts. One might celebrate the body as the site of disruption to dualistic claims to identity. Indeed the texts can be used to vindicate the argument that conceiving oneself as dualistically split does not work. For in Lorca the body/Other forces the 'real self' to admit to its existence, just as the anorexic is forced to admit to the hungers she tries to expel. And part of the treatment of anorexics is recognising the Other, allowing it to enter. However, whilst I 
would perhaps embrace this approach elsewhere, the intention of this paper is to reissue the note of caution issued by Bordo ${ }^{47}$ amongst others: the celebration of difference must also take into account that what is considered different is disturbing limits. The Other disturbs from a position of Otherness, which, for Lorca's characters at least, is an expelled, maligned, feared, position. And cultural attempts to keep the lid on Otherness, whilst they might fail, can, as the anorexic body reminds us, be brutal if not fatal.

\section{USE VALUE OF THIS APPROACH}

But what is the value of this reading of Lorca's theatre? And what can we do with it? To conclude this paper I would like to venture some further directions.

First, Lorca's texts could be used in therapeutic situations to explore symbolically in discussion, or actively in performance, the dilemmas that sufferers of eating disorders are experiencing. Nor would they be out of place on any reading list for people or carers of people with eating disorders. For, as I have argued, Lorca's texts provide an active ground for a cognitive awareness of the problem, which, according to Orbach, ${ }^{48}$ is an important stage on the road to recovery 'recognition takes place most happily when it can be linked with the possibility of other ways of coping and being in the world. Recognition is an absolutely essential step in the process towards recovery'.

In the aforementioned words, Orbach ${ }^{49}$ raises another important point: the link between eating disorders and ontology, both in the maintaining of and recovery from the disorder. In this regard, what is important in Lorca is that his texts do not merely offer possibilities for the recognition of the problem, they offer ways of breaking free from eating disorders. The need to create new ontologies, which Orbach ${ }^{50}$ identifies as crucial to the recovery from eating disorders, is a point that can be made quite forcibly through 
Lorca's dramas. As I mentioned in the example with the Mother who, at the end of Blood wedding, was no longer frightened of food, Lorca's texts can be used to exemplify the complex point that moving away from dualist models of being might lead to a more balanced relationship not only with the self, but also with food.

Second, this paper aims to respond to liberal humanist critics of Lorca by reiterating the feminist point that dualisms work against and can destroy the female. In this sense I am sympathetic towards poststructuralist readings of Lorca. Where I depart from the poststructuralist turn is in my emphasis on the insight that difference is not always experienced as liberatory. The anorexic finds the awareness of difference and fragmentation unbearable and uses rather alarming techniques to cope with it.

Third, as I stated in the beginning, writers on disordered eating stress that it constitutes a complex response to the demands and constraints of contemporary femininity involving both complicity with and rebellion against cultural norms around the gendered body. ${ }^{51}$ Viewing subjectivity in Lorca's texts from the vantage point of anorexia thus allows for an exploration of gender construction which would comprise an analysis of inscription and power as well as of individual agency within gender formations. Anorexia, after all, is not limited to women, $10 \%$ of those who seek help for anorexia are men, ${ }^{52}$ especially, according to Iain Williamson, ${ }^{53}$ gay men. This is an approach I take myself with reference to Judith Butler's ${ }^{54}$ theories of gender construction. As I have argued, cultural feminist perspectives on anorexia such as Bordo's ${ }^{55}$ or Orbach's ${ }^{56}$ stress that it is an attempt to assert control where the person feels out of control. But by trying to absent the body/ hunger, the anorexic becomes even hungrier, so people with anorexia cannot negate hunger - it continually haunts them. This parallels readings of the processes of discourse and subjectivity as described by Butler. ${ }^{57}$ According to Butler, ${ }^{58}$ subjectivity, because it is discursive, is both materialised and rendered out of control. To claim an identity such as woman one has to produce a sense 
of presence, one has to try to give one's identity a sense of coherence by absenting or Othering objects which are not deemed appropriate to a woman. The creation of what is Other to an identity is given a negative value (as we have seen with the anorexic's positing of the body as Other). So the anorexic need to expel food and make the body Other in order to maintain control and give their lives a semblance of coherence might be used to give a practical example of Butler's ${ }^{59}$ theories of identity as being formed through exclusion, through the expulsion of things that threaten its boundaries. Moreover, just like the anorexic's hunger, what is made Other to a fixed category of identity remains as a primary identification and haunts the boundaries of that identity, constantly threatening to destroy it. So gender is in perpetual conflict.

Fourth. Reading the characters from the perspective of disordered eating such as anorexia also has implications for the ways in which Lorca might be performed. In 1986 Orbach $^{60}$ said that, by attending to social or cultural positioning of women new treatment models of anorexia and other eating disorders could be found which would lead to a more empathetic relationship with the anorexic. By examining wider social and cultural currents, one could argue that anorexia is not an illness of a crazy, all consuming individual, but of an individual who is responding to normal, because culturally dominant, proscriptions of femininity. This is an important political position which has been taken up by many writers on anorexia. Let us similarly stop pathologising Lorca's female characters - especially Bernarda (who exhibits the most literal form of anorexia of all of Lorca's characters). Critical descriptions of Bernarda seem to delight in making her the wicked, demented tyrant and even strive to mythologise her pathology in the process. For Torres Nebrera,${ }^{61}$ for example, Bernarda is a frightening Gorgon 'que no era posible mirarlas de frente sin quedar petrificado', or castrating Cronos 'devorador de sus propios hijos'. If Bernarda is a tyrant, obsessed with control then we must ask ourselves why? Rather than demonising her, it is our ethical responsibility to approach Bernarda with 
empathy and sensitivity, as we should the anorexic. Furthermore, as Orbach aspired to create a more empathetic approach to eating disorders by situating them within broader social, cultural and political contexts, one might create the conditions for empathy through performance: an exciting, indeed politically important, challenge to any theatre director.

In saying all this I am of course arguing that art is not divorced from, but intertwined with everyday life. And this leads me to my fifth point: this approach might be used in a teaching situation to make Lorca's texts more immanent to students' lives. The Eating Disorders Association of Great Britain ${ }^{62}$ estimates that anorexia affects between $1-2 \%$ of young adult women, bulimia between 1 and $3 \%$ and can give no estimate of those suffering from other forms of disordered eating. At a time where anecdotal evidence suggests that our students are becoming bored with Lorca's texts, reading them through the optic of eating disorders might, then, make them modern and might keep such vibrant and lively works vibrant and lively.

\section{NOTES}

${ }^{1}$ See, for example, M. Durán, (ed) Lorca: a collection of critical essays (Englewood Cliffs, N.J.: PrenticeHall, 1962); G. Edwards, The theatre beneath the sand (London, New York: M. Boyars, 1980); L. Hardison, Federico García Lorca (New York: Frederick Ungar Publishing Co., 1984); D. Klein, Blood wedding, Yerma and the house of Bernarda Alba (Boston: Twayne, 1991); R. Lima, 'Towards the dionysiac: Pagan elements and rites in Yerma', in Lorca's legacy: Essays on Lorca's life, poetry and theatre ed. M. Durán and F. Colecchia (New York, London: Peter Lang, 1991).

${ }^{2}$ L. F. Cifuentes, García Lorca en el teatro: la norma y la diferencia (Zaragoza: Universidad de Zaragoza, 1986); P. J. Smith, 'Lorca and Foucault' in The body hispanic: Gender and sexuality in Spanish and Spanish American literature (Oxford: Oxford University Press, 1989), 105-137.

${ }^{3}$ See, for example, M. Durán, (ed) Lorca: a collection of critical essays (Englewood Cliffs, N.J.: PrenticeHall , 1962), 10; B. Frazier, La mujer en el teatro de Federico García Lorca (Madrid: Playor, 1973), 48; A. Rodríguez, 'Bernarda Alba, Creation as Defiance' Romance Notes, Vol. 21, (1980-81), 282; C. Busette, 'Libido and repression in Lorca's theatre' in Drama, Sex and Politics - Themes in Drama, 7 (Cambridge: Cambridge University Press, 1985), 173; D. Klein, Blood wedding, Yerma and the house of Bernarda Alba (Boston: Twayne, 1991), 9-10; S. Degoy, En lo más oscuro del pozo, figura y rol de la mujer en el teatro de García Lorca (Argentina: Grupo Editor Latinoamericano, 1996), 9.

${ }^{4}$ J. Butler, Bodies that matter. On the discursive limits of 'sex' (New York, London: Routledge. 1993); V. L. Enders and P. B. Radcliff ed. Constructing Spanish womanhood. Female identity in modern Spain (Albany, New York: State University of New York, 1999).

${ }^{5}$ C. Battersby, 'Her body/ her boundaries' in Feminist Theory and the Body. A Reader, ed. J. Price and M. Shildrick, (Edinburgh: Edinburgh University Press, 1999), 341-358; S. Benson, 'The Body, Health and Eating Disorders', in Identity and difference, ed. K. Woodward (Milton Keynes: The Open University, 
1997), 121-181; S. Orbach, Hunger strike: the anorectic's struggle as a metaphor for our age, 2nd edition (London: Faber and Faber Limited, 1987).

${ }^{6}$ Ibid., 119.

${ }^{7}$ S. Bordo, 'Reading the slender body', in Body/Politics, ed. M. Jacobus, E. Fox Keller and S. Shuttleworth (New York, London: Routledge, 1990), 83-112; S. Bordo, 'Anorexia nervosa: Psychopathology as the crystallization of culture’, in Knowing women. Feminism and knowledge, ed. H. Crowley and S.

Himmelweit (Milton Keynes: The Open University, 1992), 90-109; S. Bordo, 'Feminism, Foucault and the politics of the body', in Feminist theory and the body. A reader, ed. J. Price and M. Shildrick (Edinburgh: Edinburgh University Press, 1999), 246-257; S. Bordo, Unbearable weight. Feminism, western culture and the body (Berkeley, California: University of California Press, 1993).

${ }^{8}$ See J. Price and M. Shildrick, op. cit., 15-75.

${ }^{9}$ Butler, op. cit., 187.

${ }^{10}$ Ibid.

${ }^{11}$ Battersby, op. cit., 345 .

${ }^{12}$ Bordo: 1993; Butler, ibid.

${ }^{13}$ D. Lupton, Food, the body, the self (London: Sage Publications Ltd., 1996), 134-135.

${ }^{14}$ Bordo, Anorexia nervosa..., 94.

${ }^{15}$ Ibid.

${ }^{16} \mathrm{~S}$. Orbach, Fat is a feminist issue 2 (London: The Hamlyn Publishing Group, 1982), 20; D. Lupton op. cit., 134-135; C. Battersby, op. cit., 345.

${ }^{17}$ H. Bruch, Eating disorders (New York: Basic Books, 1973), 50.

${ }^{18}$ Ibid., 270.

${ }^{19}$ Bordo, op. cit., 94.

${ }^{20}$ Ibid., 94.

${ }^{21}$ Ibid., 94.

${ }^{22}$ Ibid., 95.

${ }^{23}$ Ibid., 95.

${ }^{24}$ Ibid., 94.

${ }^{25}$ Bruch, op. cit., 253.

${ }^{26}$ Bordo, Anorexia nervosa ..., 103.

${ }^{27}$ F. García Lorca, Bodas de Sangre, ed. H. Ramsden (Manchester: Manchester University Press, 1980). All quotations from Blood Wedding are from this edition.

${ }^{28}$ F. García Lorca, Yerma, ed. García-Posada, Miguel (Madrid: Espasa Calpe, 1999). All quotations from Yerma are from this edition.

${ }^{29}$ F. García Lorca, La casa de Bernarda Alba. Drama de mujeres en los pueblos de España, ed. D. Pérez Minik (Barcelona: Aymá, 1964). All quotations from Bernarda Alba are from this edition.

${ }^{30}$ Bordo, op. cit., 94.

${ }^{31}$ Bordo, ibid., 94.

${ }^{32}$ Ibid., 94.

${ }^{33}$ Ibid., 94.

${ }^{34} \mathrm{~B}$. Dijkstra, Idols of perversity: fantasies of feminine evil in fin-de-siècle culture (New York: Oxford University Press, 1986).

${ }^{35}$ R. Felski, The Gender of Modernity (Cambridge, Massachusetts, London: Harvard University Press, 1995), 187-88, 191.

${ }^{36}$ Bordo, op. cit., 94.

${ }^{37}$ Bordo, Unbearable Weight..., 13.

${ }^{38}$ Bordo, Reading the Slender Body..., 96.

${ }^{39}$ J. Dwyer, The Body At War: the Story of our Immune System (London: Dent, 1993).

${ }^{40}$ Bordo, Anorexia Nervosa..., 27.

${ }^{41}$ P. J. Smith, The Theatre of García Lorca (Cambridge: Cambridge University Press, 1998), 37.

${ }^{42}$ Eating Disorders Association (EDA), (info@edauk.com), Eating Disorder Statistics, 3. 11/09/2000. Email to: Lisa Clughen (lisa.clughen@ntu.ac.uk).

${ }^{43}$ Battersby, op. cit., 346.

${ }^{44}$ Orbach, Hunger Strike..., 143.

${ }^{45}$ Butler, op. cit., 192.

${ }^{46}$ Orbach, op. cit., 147.

${ }^{47}$ Bordo, Unbearable Weight..., 299-300.

${ }^{48}$ Orbach, op. cit., 121.

${ }^{49}$ Ibid., 121.

${ }^{50}$ Ibid., 121. 
${ }^{51}$ Benson, op. cit; Bordo, Unbearable Weight...; C. M. Counihan, 'Western Women's Prodigious Fasting', in Food and gender: identity and power, ed. C. M. Counihan, and S. L Kaplan (Amsterdam: Harwood Academic, 1998), 99-123.

${ }^{52}$ EDA, op. cit., 2.

${ }^{53}$ Williamson, Iain (1999) 'Why are gay men a high risk group for eating disturbance?' [online], European Eating Disorders Review, Volume 7, Issue 1, pp 1-4. Available at: http://www3.interscience.wiley.com/cgibin/abstract/55000975/START [Accessed 27 July 2001].

${ }^{54}$ Butler, op. cit.

${ }^{55}$ Bordo, op. cit.

${ }^{56}$ Orbach, op. cit.

${ }^{57}$ Butler, op. cit.; J. Butler, 'Melancholy Gender/Refused Identification' in Constructing Masculinity, ed. M. Berger, B. Wallis and S. Watson, (New York \& London: Routledge, 1995), 21-36.

${ }^{58}$ Butler, Bodies..., 190.

${ }^{59}$ Ibid.

${ }^{60}$ Orbach, op. cit., 18.

${ }^{61}$ G. Torres Nebrera, 'El motivo de 'La encerrada' en Lorca y Alberti. (Bernarda Alba y El Adefesio frente a frente)' in El Teatro de Lorca. Tragedia, Drama, Farsa, ed. C. Cuevas García (Málaga: Universidad de Málaga, 1995), 43-75.

${ }^{62}$ EDA, op. cit., 2. 